\title{
Pregnancies after co-culture of cumulus cells with bovine embryos derived from in-vitro fertilization of in-vitro matured follicular oocytes
}

\author{
K. Goto, Y. Kajihara, S. Kosaka, M. Koba, Y. Nakanishi and K. Ogawa \\ Laboratory of Animal Reproduction, Department of Animal Science, Faculty of Agriculture, \\ Kagoshima University, Kagoshima 890 Japan
}

\begin{abstract}
Summary. Bovine follicular oocytes surrounded by cumulus cells for more than one-third of their surface were matured, fertilized and developed in vitro utilizing a co-culture system with bovine cumulus cells. Embryos developed into blastocysts were non-surgically transferred to the uteri of cows at Day 6, 7 or 8 (Day $0=$ oestrus). Out of 6 recipient cows (19 blastocysts transferred), 3 became pregnant. One of the 3 pregnant cows carried twins.

The results of this study demonstrated the viability of embryos obtained from in-vitro maturation of bovine oocytes followed by in-vitro fertilization and culture to the blastocyst stage in vitro.
\end{abstract}

Keywords: in-vitro; maturation; ferilization; cattle

\section{Introduction}

In-vitro fertilization of oocytes would have a major impact on bovine embryo transfer (Brackett et al., 1982; Brackett, 1983). A wide variety of culture media has been used but only limited in-vitro development of preimplantation cow embryos has been reported (Brock \& Rowson, 1952; Thibault, 1966; Brinster, 1968; Sreenan, 1968; Sreenan et al., 1968; Onuma \& Foote, 1969; Seidel et al., 1971; McKenzie \& Kenney, 1973). Tervit et al. (1972) reported the development of 8-cell bovine embryos into blastocysts.

Wright et al. (1976b) obtained development of 4-8-cell bovine embryos cultured in vitro into blastocysts. Several investigators have reported that bovine embryos are capable of hatching in vitro (Renard et al., 1976; Wright et al., 1976a, b; Boone et al., 1978; Flechon \& Renard, 1978; Massip \& Mulnard, 1980). However, development of early cow embryos in vitro has generally been arrested at the 8- to 16-cell stage (Eyestone et al., 1987a, b). One of the breakthroughs to overcome this problem was the finding of a co-culture system for the culture of early bovine embryos fertilized in vitro. Co-culture of bovine embryos with bovine fibroblasts promoted embryo hatching and attachment in vitro (Kuzan \& Wright, 1982). Camous et al. (1984) reported that successful culture through the 8- to 16-cell block required the presence of an active biological component such as Day-14 trophoblastic vesicles. Voelkel et al. (1985) found that the bovine endometrial fibroblast monolayer system was excellent for both short- and long-term culture of halved bovine embryos. Eystone et al. (1987b) obtained the development of bovine embryos (5- to 8-cell) into blastocysts in a co-culture system utilizing oviducal epithelium.

In contrast, Kajihara et al. (1987) and Y. Fukuda (personal communication) have reported that the co-culture of bovine embryos with bovine cumulus cells is an excellent system for the in-vitro development of embryos fertilized in vitro: one-cell embryos developed into blastocysts and 
hatched blastocysts, but the viability of embryos (blastocysts) obtained from this system after their transfer to the cow uterus remains to be examined. Therefore, we conducted an experiment to verify their viability.

\section{Materials and Methods}

Collection of oocytes. The ovaries were collected from cows at a local slaughter house and brought to the laboratory in physiological saline $(0.85 \%(w / v) ~ N a C l)$ at $32-38^{\circ} \mathrm{C}$ within $2 \mathrm{~h}$. Follicular oocytes $(5-10 /$ ovary) were collected by puncturing follicles of diameter $1-7 \mathrm{~mm}$ with a needle.

Culture of oocytes. After washing twice with Whittingham's modified Dulbecco's phosphate-buffered saline (mPBS) (Whittingham, 1971) and once with the maturation medium (25 mM-Hepes TCM 199 with Earle's salts; Gibco, Cat. 380-2340, NY, U.S.A.) supplemented with 5\% neonatal calf serum (Gibco, Lot. 22P-4457), the oocytes (60-90 oocytes) surrounded by cumulus cells for more than one-third of their surface (Fig. 1) were introduced into the maturation medium $(2.5 \mathrm{ml})$, covered with paraffin oil (Nakarai Chemical, No. 26117, Kyoto, Japan), in a polystyrene culture dish $\left(35 \mathrm{M} / \mathrm{M}\right.$, Termo, Tokyo, Japan) and cultured for $19-22 \mathrm{~h}$ in a $\mathrm{CO}_{2}$ incubator $\left(5 \% \mathrm{CO}_{2}\right.$ in air) at $39^{\circ} \mathrm{C}$.
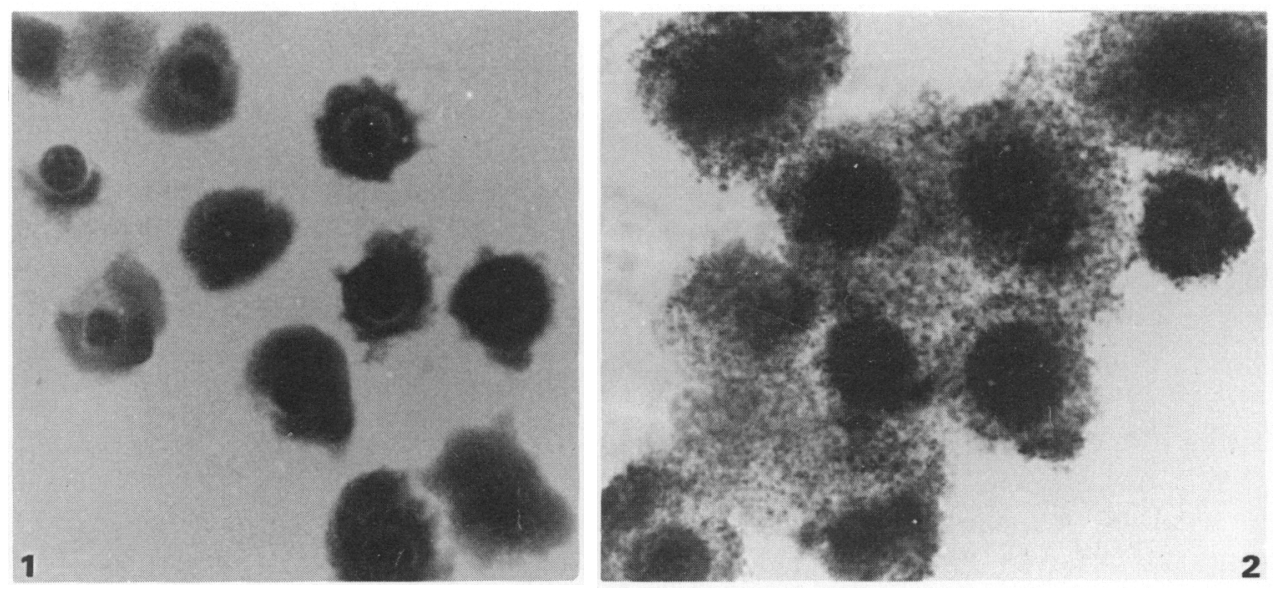

Fig. 1. Oocytes before maturation.

Fig. 2. Oocytes after maturation. Expansion of cumulus cells is visible.

Sperm preparation. Frozen semen prepared from epididymal spermatozoa in $0.5 \mathrm{ml}$ plastic straws was thawed in hot water $\left(32-35^{\circ} \mathrm{C}\right)$ and then washed 3 times with BO medium (Brackett \& Oliphant, 1975) without bovine serum albumin but supplemented with $5 \mathrm{mM}$-caffeine by centrifugation at $700 \mathrm{~g}$ for $5 \mathrm{~min}$. Then the spermatozoa were preincubated for $2-3 \mathrm{~h}$ in a $\mathrm{CO}_{2}$ incubator $\left(5 \% \mathrm{CO}_{2}\right.$ in air) at $39^{\circ} \mathrm{C}$ as a $110 \mu \mathrm{microdrop}\left(15-18 \times 10^{6} \mathrm{cells} / \mathrm{ml}\right)$ in $\mathrm{BO}$ medium containing bovine serum albumin $(5 \mathrm{mg} / \mathrm{ml}$; Sigma, A-4387, St Louis, MO, U.S.A.) and caffeine $(2.5 \mathrm{~mm})$ before insemination. The microdrops were covered with liquid paraffin.

Insemination and subsequent culture. The method used was similar to that of Kajihara et al. (1987). Briefly the following procedure was used. After incubation for 19-22 h the cumulus-oocyte complexes (Fig. 2) were transferred to the sperm microdrop (about 15 oocytes/microdrop). After $6 \mathrm{~h}$ of insemination, the ova with cumulus cells were transferred into the development medium ( $25 \mathrm{mM}$-Hepes TCM 199 supplemented with $2 \cdot 5-10 \%$ calf serum) and cultured for further development in a $\mathrm{CO}_{2}$ incubator at $39^{\circ} \mathrm{C}$. The culture medium $(2.5 \mathrm{ml})$ in a polystyrene dish $(35 \mathrm{M} / \mathrm{M})$ was covered with liquid paraffin. The cumulus cells surrounding embryos were removed by pipetting after insemination for $72-96 \mathrm{~h}$ but the cumulus cell layer (forming a monolayer at this time) attached to the bottom of culture dish was not removed and the embryos were cultured on this layer. The incubation medium was replaced with new medium every $36-48 \mathrm{~h}$. All of the culture media used were supplemented with antibiotics (100i.u. penicillin $/ \mathrm{ml}+100 \mu \mathrm{g}$ streptomycin $/ \mathrm{ml}$ ). The embryos were examined under the microscope every $24 \mathrm{~h}$ after the removal of cumulus cells from the embryos. 

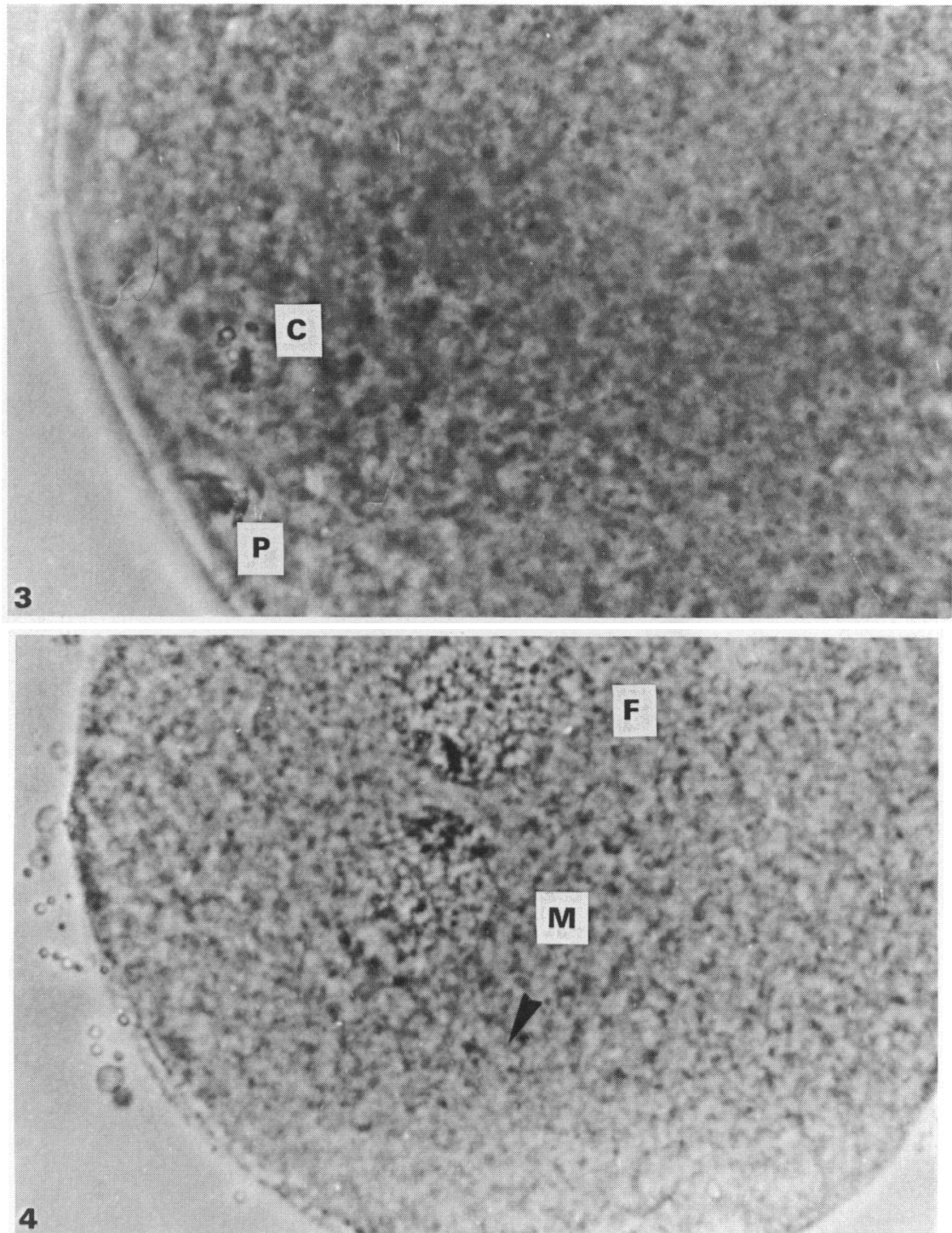

Fig. 3. Matured oocyte (metaphase II), showing first polar body (P) and metaphase chromosome $(\mathrm{C})$.

Fig. 4. Fertilized ovum, showing a male pronucleus (M), female pronucleus (F) and a sperm tail (arrow).

Maturation and fertilization rates. Some of the ova used were randomly picked up for the calculation of maturation and fertilization rates. Maturation and fertilization rates of ova were examined $23-24 \mathrm{~h}$ after maturation and $20 \mathrm{~h}$ after insemination, respectively, after fixing ova in methanol:acetic acid $(3: 1, \mathrm{v} / \mathrm{v})$ and then stained with $1 \%$ aceto-orcein for microscopic evaluation. The ova exhibiting a metaphase II chromosome figure with the first polar body (Fig. 3) were regarded as matured. Ova which had one set of male and female pronuclei and one sperm tail (Fig. 4) were regarded as normally fertilized.

Embryo transfer and pregnancy diagnosis. Embryos that developed into blastocysts (Figs 5 \& 6) were nonsurgically transferred to the uteri of cows at Day 6,7 or 8 (Day $0=$ oestrus) of the cycle. Pregnancy diagnosis was done by uitrasound and rectal palpation after 55 days. 

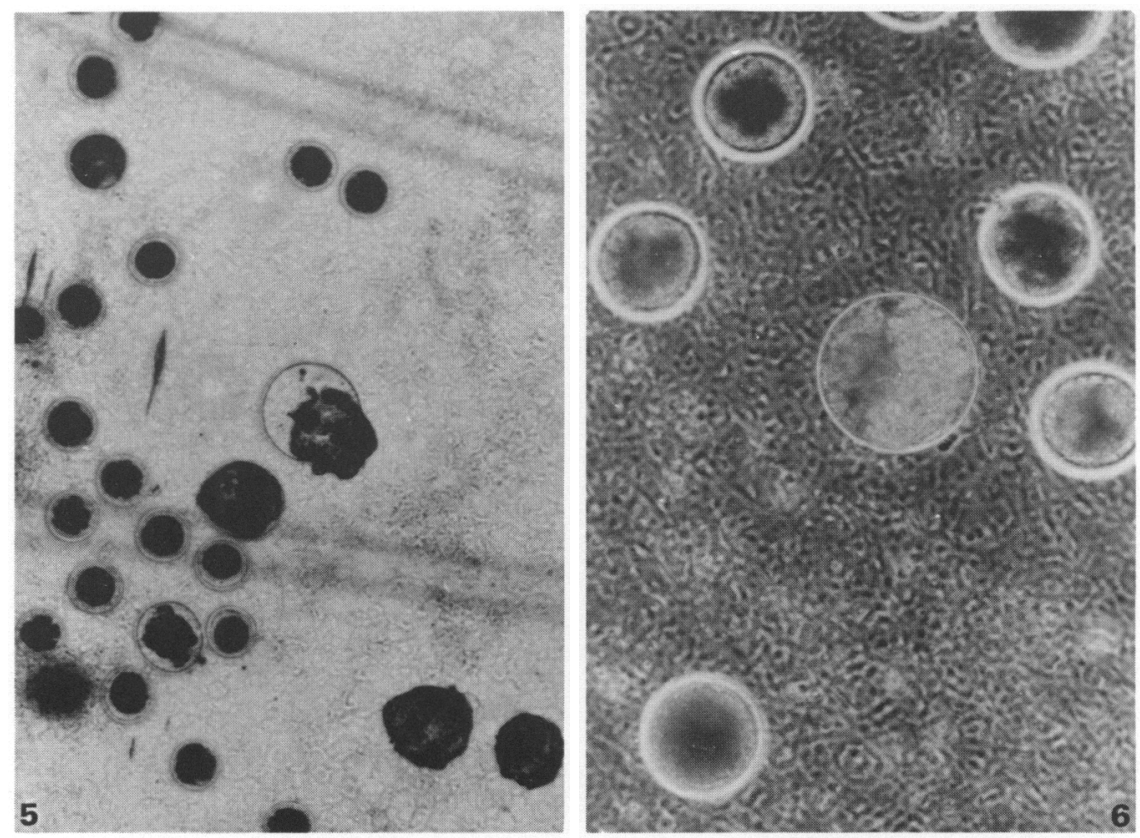

Fig. 5. Overall view of the cultured ova at 10 days after in-vitro fertilization. Hatching and hatched blastocysts are visible.

Fig. 6. One of the two expanded blastocysts transferred to Cow 4 on 11 May 1987. The cumulus cell layer at the bottom of the culture dish is visible.

\section{Results}

The maturation rate of oocytes examined after $23-24 \mathrm{~h}$ of incubation was $82.9 \%(63 / 76)$. The fertilization rate examined after $20 \mathrm{~h}$ of insemination was $63 \cdot 0 \%(160 / 254)$.

After in-vitro maturation and fertilization (6 trials), 25\% (171/684) of oocytes used developed to at least the 8-cell stage by 3-4 days after in-vitro fertilization. At 5-6 and 7-8 days after in-vitro fertilization development to morulae and blastocysts was $21 \cdot 1 \%(144 / 684)$ and $15 \cdot 1 \%(103 / 684)$, respectively.

The results of the embryo transfer are shown in Table 1 . A female calf $(41 \mathrm{~kg})$ born to Cow 4 appears to be completely normal.

\section{Discussion}

In-vitro fertilization of cow ova began in the 1970s (Edwards, 1973; Bregulla et al., 1974; Iritani \& Niwa, 1977; Brackett et al., 1978) and, in 1981, the first calf was born after in-vitro fertilization (Brackett et al., 1982). Although other calves have since been born (Brackett et al., 1984), the technology used has been considered unsuitable for field application. This is mainly due to the surgical approach that was required for the recovery of ova and for the transfer of embryos to the oviduct of recipients.

Lambert et al. (1986) obtained calves by using in-vivo matured follicular oocytes collected by laparoscopy and by incubation of the in-vitro fertilized eggs in rabbit oviducts before surgical or non-surgical transfer to the uterus of recipient heifers. Hanada (1986) obtained calves from 
Table 1. Summary of embryo transfers

\begin{tabular}{|c|c|c|c|c|c|}
\hline $\begin{array}{l}\text { Recipient } \\
\text { cow }\end{array}$ & $\begin{array}{l}\text { Day of } \\
\text { oestrus }\end{array}$ & $\begin{array}{l}\text { Day of } \\
\text { transfer }\end{array}$ & $\begin{array}{c}\text { Side of } \\
\text { uterine } \\
\text { horn }(C L)\end{array}$ & $\begin{array}{l}\text { Stage and no. } \\
\text { of embryos } \\
\text { transferred } \\
\text { (days after } \\
\text { insemination }\end{array}$ & Diagnosis \\
\hline 1 & 25 Feb. 1987 & 5 March 1987 & $\begin{array}{l}\text { Left (CL) } \\
\text { Right }\end{array}$ & $\begin{array}{r}\text { ExBl } 1(7) \\
\text { Bl } 1(7)\end{array}$ & Not pregnant \\
\hline 2 & 27 Feb. 1987 & 7 March 1987 & $\begin{array}{l}\text { Left (CL) } \\
\text { Right }\end{array}$ & $\begin{array}{l}\text { ExBl I (9) } \\
\text { ExBl } 2(9)\end{array}$ & Not pregnant \\
\hline 3 & 9 March 1987 & 16 March 1987 & $\begin{array}{l}\text { Left (CL) } \\
\text { Right }\end{array}$ & $\begin{array}{l}\text { ExBl } 1(10) \\
\text { ExBl } 1(10)\end{array}$ & Not pregnant \\
\hline 4 & 5 May 1987 & 11 May 1987 & $\begin{array}{l}\text { Left (CL) } \\
\text { Right }\end{array}$ & $\begin{array}{r}\text { Bl } 2(8) \\
\text { ExBl } 2(8)\end{array}$ & Pregnant \\
\hline 5 & 23 July 1987 & 31 July 1987 & $\begin{array}{l}\text { Left (CL) } \\
\text { Right }\end{array}$ & $\begin{array}{l}\text { ExBl } 2(8) \\
\text { ExBl } 1(8)\end{array}$ & Pregnant \\
\hline \multirow[t]{2}{*}{6} & 4 Sept. 1987 & 10 Sept. 1987 & $\begin{array}{l}\text { Left } \\
\text { Right (CL) }\end{array}$ & $\begin{array}{l}\text { B1 } 1 \text { (7) } \\
\text { Bl } 2(7)\end{array}$ & Pregnant \\
\hline & & 11 Sept. $1987^{*}$ & Left & ExBl $2(8)$ & (Twin) \\
\hline
\end{tabular}

$\mathrm{Bl}=$ blastocyst, $\mathrm{ExBl}=$ expanded blastocysts; $\mathrm{CL}=$ presence of functional corpus luteum.

*Another transfer because blood was observed at the tip of the straw used for transfer the day before.

follicular oocytes matured and fertilized in vitro followed by incubation of embryos in rabbit oviducts before non-surgical transfer to the uterus of cows.

In the present study we have obtained pregnancies from cow oocytes which had bee.1 matured, fertilized and developed in vitro by utilizing a co-culture system with bovine cumulus cells before their non-surgical transfer to the cow uterus. We have obtained a high rate $(83 \%)$ of nuclear maturation in our culture system. This is partly due to the fact that cumulus cells surrounding the oocyte expanded well during the maturation process. The importance of cumulus expansion during the maturation process has been suggested by Ball et al. (1984).

Although the percentage of embryos developed to blastocysts was low (15.1\%), the results of this study have verified the viability of embryos (blastocysts) developed in a co-culture system with bovine cumulus cells. Further trials have resulted in 5 pregnancies out of 11 recipient cows which had received frozen-thawed blastocysts (2-3 blastocysts/recipient) obtained from the same method described in this paper. One out of 5 cows was carrying twins. Therefore, the blastocysts obtained from our culture system can be stored in liquid nitrogen.

The method described in this paper seems to be a simple and practical way to obtain calves from in-vitro fertilization. Furthermore, culture systems such as that described here should prove useful for studies of early embryonic development in vitro and for the application of embryonic manipulation procedures.

We thank Dr K. Hamana, Department of Veterinary Medicine, Kagoshima University, for help in pregnancy diagnosis; and $\mathrm{Mr}$ T. Oku, Mr M. Fujiyama and Mr Y. Yoshida, Nagasaki Prefectural Livestock Experimental Station, for help in embryo transfers.

\section{References}

Ball, G.D., Leibfried, M.L., Ax, R.L. \& First, N.L. (1984)

Maturation and fertilization of bovine oocyte in vitro. J. Dairy Sci. 67, 2775-2785.
Boone, W.R., Dickey, J.F., Luszcz, L.J., Dantzler, J.R. \& Hill, J.R. (1978) Culture of ovine and bovine ova. $J$. Anim. Sci. 47, 908-913. 
Brackett, B.G. (1983) A review of bovine fertilization in vitro. Theriogenology 19, 1-15.

Brackett, B.G., Oh, Y.K., Evans, J.F. \& Donawick, W.J. (1978) In vitro fertilization of cow ova. Theriogenology 9, Abstr. 89.

Brackett, B.G. \& Oliphant, G. (1975) Capacitation of rabbit spermatozoa in vitro. Biol. Reprod. 12, 260-274.

Brackett, B.G., Bousquet, D., Boice, M.L., Donawick, W.J., Evans, J.F. \& Dressel, M.A. (1982) Normal development following in vitro fertilization in the cow. Biol. Reprod. 27, 147-158.

Brackett, B.G., Keefer, L.L., Troop, L.G., Donawick, W.J. \& Bennett, K.A. (1984) Bovine twins resulting from in vitro fertilization. Theriogenology 21, Abstr. 224.

Bregulla, K., Gerlach, U. \& Hahn, R. (1974) Versuche zur extrakorporalen Reitung, Befruchtung und Embryoenzucht mit Rinderkeimzellen. Dtsch. Tierarztl. Wochenschr. 81, 465-470.

Brinster, R.L. (1968) In vitro culture of mammalian embryos. J. Anim. Sci. 27, 1-15.

Brock, H. \& Rowson, L.E.A. (1952) The production of viable bovine ova. J. agric. Sci., Camb. 42, 479-482.

Camous, S., Heyman, Y., Méziou, W. \& Ménézo, Y. (1984) Cleavage beyond the block stage and survival after transfer of early bovine embryos cultured with trophoblastic vesicles. J. Reprod. Fert. 72, 479-485.

Edwards, R.G. (1973) Physiological aspects of human ovulation, fertilization and cleavage. J. Reprod. Fert., Suppl. 18, 87-101.

Eyestone, W.H., Leibfried-Rutledge, M.L., Northey, D.L., Gilligan, B.G. \& First, N.L. (1987a) Culture of one- and two-cell bovine embryos to the blastocyst stage in the ovine oviduct. Theriogenology 28, 1-24.

Eyestone, W.H., Vignieri, J. \& First, N.L. (1987b) Co-culture of early bovine embryos with oviductal epithelium. Theriogenology 27, Abstr. 228.

Flechon, J.-E. \& Renard, J.-P. (1978) A scanning electron microscope study of the hatching of bovine blastocysts in vitro. J. Reprod. Fert. 53, 9-12.

Hanada, A. (1986) In vitro fertilization of bovine oocytes. Consultant for Animal Science 258, 10-15 (in Japanese).

Iritani, A. \& Niwa, K. (1977) Capacitation of bull spermatozoa and fertilization in vitro of cattle follicular oocytes matured in culture. J. Reprod. Fert. 50, 119-121.

Kajihara, Y., Goto, K., Kosaka, S., Nakanishi, Y. \& Ogawa, K. (1987) In vitro fertilization of bovine follicular oocytes and their development up to hatched blastocysts in vitro. Jpn. J. Anim. Reprod. 33, 173-180.

Kuzan, F.B. \& Wright, R.W. (1982) Observations on the development of bovine morulae on various cellular and noncellular substrata. J. Anim. Sci. 54, 811-816.

Lambert, R.D., Sirard, M.A., Bernard, C., Béland, R. Rioux, J.E., Leclerc, P., Ménard, D.P. \& Bedoya, M. (1986) In vitro fertilization of bovine oocytes matured in vivo and collected at laparoscopy. Theriogenology 25, 117-132.

Massip, A. \& Mulnard, J. (1980) Time-lapse cinematographic analysis of hatching of normal and frozenthawed cow blastocysts. J. Reprod. Fert. 58, 475-478.

McKenzie, B.E. \& Kenney, R.M. (1973) In vitro culture of bovine embryos. Am. J. vet. Res. 34, 1271-1276.

Onuma, H. \& Foote, R.H. (1969) In vitro development of ova from pre-puberal cattle. J. Dairy Sci. 52, 1085-1087.

Renard, J.P., Buisson, F.M., Wintenberger-Torres, S. \& Menezo, Y. (1976) In vitro culture of cow embryos from Day 6 and Day 7. In Egg Transfer in Cattle, pp. 159-164. Ed. L. E. A. Rowson. Commission of the European Communities. Luxembourg.

Seidel, G.E., Jr, Larson, L.L., Spilman, C.H., Hahn, J. \& Foote, R.H. (1971) Culture and transfer of calf ova. $J$. Dairy Sci. 54, 923-926.

Sreenan, J. (1968) In vivo and in vitro culture of cattle eggs. Proc. 6th Int. Congr. Anim. Reprod. \& A.I., Paris, pp. 577-580.

Sreenan, J., Scanlon, P. \& Gordon, I. (1968) Culture of fertilized cattle eggs. J. agric. Sci., Camb. 70, $183-185$.

Tervit, H.R., Whittingham, D.G. \& Rowson, L.E.A. (1972) Successful culture in vitro of sheep and cattle ova. J. Reprod. Fert. 30, 493497.

Thibault, C. (1966) La culture in vitro des oeufs de vache. Annls Biol. anim. Biochim. Biophys. 6, 159-164.

Voelkel, G.F., Amborski, G.F., Hill, K.G. \& Godke, R.A. (1985) Use of a uterine-cell monolayer culture system for micromanipulated bovine embryos. Theriogenology 24, 271-281.

Whittingham, D.G. (1971) Survival of mouse embryos after freezing and thawing. Nature, Lond. 233, 125-126.

Wright, R.W., Anderson, G.B., Cupps, P.T. \& Drost, M. (1976a) Blastocyst expansion and hatching of bovine ova cultured in vitro. J. Anim. Sci. 43, 170-174.

Wright, R.W., Anderson, G.B., Cupps, P.T. \& Drost, M. (1976b) Successful culture in vitro of bovine embryos to the blastocyst stage. Biol. Reprod. 14, 157-162.

Received 3 November 1987 